\title{
Changes in the functional structure of small towns in the least developed regions of Poland
}

\author{
Marcin Bogdański* \\ University of Warmia and Mazury in Olsztyn, Poland
}

The main objective of this work was to describe the functional structure of small towns located in the least-developed Polish voivodships (the so-called eastern Polish wall) and its changes between 2008 and 2018. An additional goal was to measure the diversification level of the functions performed by these towns. The results show that the structure of functions performed by small towns in eastern Poland was relatively uncompetitive and characterized by high stability over time. The structure was dominated by functions related to non-market services and industry, which in their case do not generate high added value. The studied structures were also relatively homogenous. The combination of such features in the long term may slow down the economic growth of the surveyed towns and regions in which they are located.

Key Words: small towns, functional structure, economic base, voivodships, economic growth.

Article Info: Received: January 14, 2021; Revised: November 4, 2021; Accepted: November 6, 2021; Online: November 30, 2021.

\section{Introduction}

Urbanization is one of the essential contemporary socio-economic megatrends, next to globalization and digitization. Since 2007, for the first time in the history

\footnotetext{
* Correspondence address

Address: Faculty of Economics, University of Warmia and Mazury in Olsztyn, Prawocheńskiego 19 Street, 10-720 Olsztyn, Poland Phone: +48 8952343 30| Email: marcin.bogdanski@uwm.edu.pl

(C)2021 Human Geographies; The authors
}

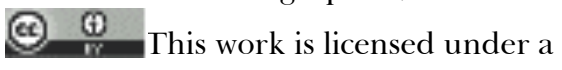

Creative Commons Attribution 4.0 International License. DOI:10.5719/hgeo.2021.152.4 
of human civilization, more people have lived in cities than in rural areas. Thus, urbanized areas continue to concentrate an increasing part of the social, economic and intellectual potential. A natural consequence of the progressing urbanization process is the growing interest in this issue on the part of many researchers - from the humanities, through economics, geography, to technical sciences. However, in the case of research in the field of economics and economic geography, there is an evident disproportion in terms of the subject of analyses.

Particular attention is paid to large cities and metropolitan areas, while issues related to the functioning of small and medium-sized towns are taken up relatively less frequently (Bell \& Jayne, 2009; Brenner \& Schmid, 2014; Davidson \& Iveson, 2015; Servillo \& Russo, 2017, Servillo et al. al, Stoica et al., 2020, Steinführer \& Grossmann 2021). On the one hand, it is justified because, in many developed economies, large cities and their functional areas are characterized by the highest level dynamics of economic growth (Dijkstra et al., 2013; David et al., 2013; Bogdański, 2017a). On the other hand, it should be considered that small and medium-sized towns are still an important part of many national socioeconomic systems. For example, in the European Union (EU), 38\% of inhabitants live in small and medium-sized towns with a population of 5,000 to 100,000. For the smallest cities, less than 5,000 inhabitants, $19 \%$ of the EU's population is represented, while for large cities, this percentage reaches $30 \%$ (Hamdouch et al., 2017, Servillo et al., 2017). Globally, the percentage of people living in small and medium-sized cities is even more remarkable and amounts to 56\% (European Union, 2011).

As Vaishar et al. (Vaishar 2016) note, the role of small and medium-sized towns in national and regional economies can be viewed from two perspectives. First, from the point of view of large cities and metropolitan areas, small towns constitute a relatively insignificant element of the settlement system with low development and innovation potential. They are the location of industrial companies leaving large cities due to their nuisance and low competitiveness (Smętkowski \& Gorzelak, 2001). On the continuum axis from urbanized to rural areas, in terms of socio-economic characteristics, small towns are much closer to the latter (Vaishar et al., 2016, Stoica et al., 2020). Second, looking at the role of small towns from the perspective of rural areas, they may constitute growth poles for their surroundings. Being the source of income and public services (also of higher order services like tertiary education, hospitals, cultural services), they constitute the necessary base for the transformation of rural areas from an economy based on agriculture to a more diversified and modern production structure (Erickcek \& McKinney, 2006, Lazzeroni et al., 2013, Heffner \& Twardzik, 2015, Wirth et al., 2016, Lupascu, 2020). This relatively new approach results from the observation that in the realities of the new economic paradigm, growth and development are less dependent on the scale of production or the size of the city. More important is the ability to adapt to rapidly changing market conditions and to the dynamic technological and organizational environment. The development possibilities of cities depend mostly on the degree of their integration with the national and international network of urban centres, on the 
quality and availability of human and social capital, on flexible specialization in the manufacturing of products and services and on competitive production structure. As a result, the hierarchy of urban centres may be flattened by the growing importance and dynamic economic development of small and mediumsized urban centres. It is the features of small and medium-sized towns which allow faster and more effective adaptation to the changing economic conditions (Bogdański, 2017a).

Therefore achieving cohesion at the economic and social level (both on national and on regional scale) is not possible without a polycentric network of cities and a dynamic and sustainable development of small and medium-sized towns (Skrzyp, 2002, Stocia et al., 2020). Hence, it seems extremely important to analyse the factors shaping the economic growth and development of small and medium-sized cities in different countries and different economic environments.

The main objective of the paper was to describe the functional structure of small towns located in peripheral Polish voivodships (the so-called eastern Polish wall with Warminsko-Mazurskie, Podlaskie, Lubelskie, and Podkarpackie) and its changes in 2008-2018. An additional goal was to measure the level of diversification of the functions performed by the above towns. The research hypothesis was that small towns in 2008-2018 were characterized by an unfavourable functional structure with a significant dominance of industry and non-market services. They were also characterized by a low degree of diversification of the economic base. In the author's opinion, this is one of the factors that permanently limits the development potential of the studied towns, thus conditioning the relatively lower level of economic growth of the voivodships in eastern Poland. Therefore, achieving the intended research goal will broaden the knowledge on selected determinants of the economic development of small towns in peripheral regions. It may also be some stimulus in the discussion on theoretical and practical aspects of regional economic convergence.

The author is not aware of similar publications, neither in relation to the Polish economy nor other European countries. As Porshe et al. (2019) note, researches on the economic conditions of functioning and development of small towns usually took the form of case studies. There are relatively small studies that cover a large number of such centres from more than one region and which are also based on statistical analysis. The author's observations allow stating that this is true not only concerning Germany but also in a broader European perspective. The studies of a more comprehensive nature include the analysis of Novotny et al. (2016), Vaishar et al. (2016), Stoica et al. (2020), partially also Hamdouch et al. (2017). With regard to small towns in Poland researches on these centres were usually limited to individual regions (Czapiewski et al., 2016; KoneckaSzydłowska, 2016; Górak \& Krysiński, 2017; Stettner, 2017, Świdyński \& Świdyńska, 2018; Olejniczak-Korcelli, 2020) or selected, most often demographic aspects of their functioning (Krzysztofik \& Szmytke, 2018; Wołyniec, 2019, Cienkosz, 2020). In this context, the presented analysis is unique because it is based on objective, numerical data showing the change in the functional structure of small towns in the period including the economic crisis of 2008-2011, as well as 
a relatively large number of centres covered by the study - all small towns located in four voivodeships located on the eastern border of Poland.

\section{The functions of cities and their diversity as a determinant of economic growth}

The social and economic significance of cities results mainly from the functions they perform in national and international settlement and economic systems. Their functions determine their place in the hierarchy of other settlements (Wójcik \& Tobiasz-Lis, 2016). The functions of cities in geographic sciences, including economic geography, are defined in various ways. Usually, they are described in the context of dominant activities, forming the basis of the economic potential of cities. However, this causes the risk of perceiving functions subjectively. To avoid this, one needs to take into account the city's relationship with its surroundings which is a point of reference for analysing its significance in a socio-economic space and determining the types of activities undertaken in its area (Czornik, 2004). One should define the role of cities as elements in a functional whole and specify the structure of this whole. In this perspective, with reference to the theory of the urban economic base, the functions of a city are defined as types of activities in which a surplus of employees in relation to the structure of employees in the region can be observed (Suliborski, 2010).

The concept of the economic base of cities has a relatively long tradition, and considerations on its nature and significance as determinants of economic growth constitute an important part of economics and economic geography. The period of particularly great interest in these issues falls in the second half of the $20^{\text {th }}$ century. The contemporary understanding of the urban economic base is based on the thesis that economic activity conducted in cities can be divided into two groups or sectors - exogenous (basic, city-forming) and endogenous (servicing, maintenance, supplementary). The first sector is made up of economic entities producing goods and services that are sold to buyers located outside the city limits. They make up the economic base and constitute the basis for the socioeconomic development of the city. The endogenous sector includes activities involved in producing goods and services that are sold locally and serve the needs of the city's inhabitants and users. Hence, the total value of production in a city is the sum of the production of sectors that form the economic base sector and the endogenous sector (Krikelas, 1992).

The increase in the scale of exogenous activities causes an increase in the income of entities involved in this activity and, as a result, an increase in demand (consumption and investment) within the urban economy. New needs arise, and their fulfilment requires the creation of new goods, the emergence of new businesses and new types of activities (Stawasz, 2016). In this concept, the city is considered a system of integrated, interacting elements; hence the growth of the exogenous sector initiates the development of other elements of the urban socioeconomic system. The impulse, the source of which is the exogenous sector, activates the multiplier mechanism, leading to the development of endogenous 
activities and thus the development of the entire city (Sokołowski, 2008). Despite some reservations about the correctness of selected assumptions and theses put in the theory about the urban economic base - Krikelas (1992) makes an exhaustive discussion in their historical perspective - and its validity in the conditions of the ongoing transformation of the world's economy towards knowledge-driven economy (Christofakis \& Gkouzos, 2014; Markusen, 2007; Rutland \& O’Hagan, 2007 ) in the literature on economic geography, one can come across the view that there are only two proven theories comprehensively explaining the regularities and dependencies of the functional development of cities - the theory of central places and the economic base theory (Walkiewicz, 2006).

Hence, by assessing the structure of the urban economic base, one can also define the structure of functions performed by a city. Moreover, this structure is one of the determinants as well as the measures of the level of economic growth. Nowadays, the fastest-growing urban centres include those in which the production structure is dominated by market services and high-end industry (Guan et al., 2018; Christofakis \& Gkouzos, 2014). This puts large cities in a privileged position because they have greater potential in terms of human capital, technical and social infrastructure and other soft location factors that are particularly desirable by enterprises operating in the most technologically advanced industries.

Brunelle (2013) points to a similar aspect of socio-economic structures that inhibits small towns' more dynamic growth. Referring to the concept of Vernon's product life cycle, the author notices that the most profitable production stages which generate the highest added value and thus create the greatest potential for economic growth - research and development, prototyping - are usually located in large cities. This is due to the location advantages of large cities, mainly in terms of human capital. When the design is ready and the production technology is developed, the production process is moved to smaller cities to minimize costs, including wages. However, it generates weaker growth impulses for local economies (Brunelle, 2013). Small towns also offer more minor agglomeration benefits, which may also inhibit their growth, especially if they specialize in less competitive production industries (Dube et al., 2016).

It should also be emphasized that service enterprises, in comparison with industrial ones, develop stronger economic ties with other local entities, increasing the cohesion of regional economies, which also contributes to the development of social capital (Christofakis \& Gkouzos, 2014). That is why the dominance of market services among the functions performed by a city might be seen as stimuli for economic growth.

Considering the importance of the production structure in the context of creating the basis for long-term and stable economic growth of a city, one should also take into account the degree of its diversification. Only a modern, competitive and diversified production structure is such a permanent element of the local economic potential that ensures a high rate of stable production growth. There are several premises for this. First of all, a high degree of product diversification is a factor that shapes urban resilience. Its development reduces the likelihood of 
a sharp reduction in production and employment due to the collapse of the external demand for goods produced in the city (Masik \& Sagan, 2016). A high level of product diversification also favours the influx of new enterprises, which in order to gain new markets must be characterized by a higher level of innovation and creativity in meeting the needs of their clients. In effect, it increases the level of innovation of the local economy (Duranton \& Puga, 2000) and promotes the creation of jobs (Black \& Henderson, 2003). There is also some evidence that the diversified structure of the urban economy favours a better use of scale economies, reduces transaction costs and increases the competitiveness of local enterprises (Quigle, 1998). Finally, the diversified and modern structure of urban production allows enterprises to quickly adapt their offer to the changing market conditions and the consumers' preferences (Kemeny \& Storper, 2015). Hence, in the conducted analyses, apart from determining the functional structure of small towns in peripheral voivodships in Poland, the level of diversification of urban production was also measured.

\section{Methodology}

Functions of cities are defined as those types of activities (identified with PKD sections) in which there was a surplus of employees in relation to the employment structure of the whole voivodship (region). PKD or Polska Klasyfikacja Działalnośc (Polish Classification of Activities) is a conventional and hierarchical classification system of economic activities used for statistical purposes in Poland. It divides all types of production into five classification levels, from a section - the most capacious category - to subclasses. The sections of economic activity are symbolized by letters from A to U.

The choice of the regional-voivodship economy as a reference point for calculating the size of the economic base of cities results from the methodological limitations of the indicators used. As shown by the results of comparative research described by Jerczyński (1971) and Thulin (2014), the adoption of a too-small area (for example, a poviat - in a Polish administration system a poviat is a local government unit of a second order. It is situated between gmina - the smallest local government unit and a voivodship which is a unit of regional governance) as a reference point carries the risk of excessive estimation of the exogenous sector. Conversely, the adoption of a too large spatial reference unit (for example, a country) may lead to an underestimation of exogenous employment. According to McFarlane et al. (2016), describing and understanding the changing nature of economies and their functions is possible within the economic base theory. Hence, determining the structure of the examined cities' functions required identifying the types of activities with the surplus of employees. The overall size and the structure of this surplus determine the size and the structure of the urban economic base. In doing so, one of the indirect methods of calculating the size of the urban economic base was used - the indicator of surplus employees $\left(\mathrm{I}_{\mathrm{SE}}\right)$. It is calculated according to the formula (Sokołowski, 2008): 


$$
\mathrm{I}_{\mathrm{SE}}=\mathrm{E}_{\mathrm{I}} \mathrm{M}-\left(\mathrm{EM}^{*} \frac{E i R}{E R}\right), \text { where }
$$

- EiM - employment in the activity $i$ in a small city,

- EM - total employment in a small town;

- EiR - employment in the activity $i$ in a region (voivodship);

- ER - total employment in a region (voivodship).

Next, aggregation of employment in certain sections of PKD to production sectors was made, and their share in the total number of employees in exogenous activity was calculated to assess the structure of their functions due to economic sectors. Sectors of production consisted of the following PKD sections:

- Industrial production (I) - sections B (mining and quarrying), C (industrial processing), D (production and supply of electricity and gas), E (water supply, sewage and waste management), F (construction);

- Market services (M) - sections G (wholesale and retail trade, repair of motor vehicles and motorcycles), $\mathrm{H}$ (transport and warehouse management), I (accommodation and catering services), J (information and communication), K (finance and insurance), L (real estate market services), M (professional, scientific and technical activities), N (administration services and support activities), R (culture, entertainment and recreation), $\mathrm{S}$ (other service activities), $\mathrm{T}$ (households with employees; households producing goods and providing services for their own needs), U (organizations and extraterritorial teams);

- Non-market services $(\mathrm{N})$ - sections $\mathrm{O}$ (public administration and national defense, compulsory social security), $\mathrm{P}$ (education), $\mathrm{Q}$ (health care and social assistance).

In order to determine the city types due to the nature of the economic base, the methodology of the Ossana triangle was used (Sokołowski, 2008). Towns of types "I - industry"," M - market services"," N - non-market services" include units in which one of the sectors is characterized by absolute dominance (over $75 \%$ ) in the structure of employees. Mixed types (IM, IN, NM) are characterized by a significant dominance of one of the sectors $(37.5 \%-75.0 \%)$ and a large share of the second sector, however, not exceeding $50 \%$ of employees. Finally, the structure in which each sector is characterized by a similar share in all employees (in the range of $25.0 \%-50.0 \%$ ) is called a balanced structure. In order to measure the level of functional structure diversification of the examined towns, the Amemiya index (IED) was calculated (Sokołowski, 2008):

$$
\mathrm{IED}=\sum_{i=1}^{m} \frac{m}{m-1}\left(\frac{\operatorname{EexiMj}}{\operatorname{EexMj}}-\frac{1}{m}\right)^{2}, \text { where }
$$

- $\quad$ IED - index of economic diversification of the city's exogenous sector;

- $\quad \mathrm{m}$ - number of activities (PKD sections) used in the analysis (19);

- $\quad$ ExiMj - exogenous employment in the $i$ activity in the city of $\mathrm{Mj}$;

- $\quad \mathrm{EexMj}$ - total exogenous employment in the city of $\mathrm{Mj}$. 
This index has a value of 0 to 1 , whereas, in the present analyses, the results were multiplied by 1,000, which allowed for a more accessible presentation. Low values of the IED indicate the existence of diversified employment and production structure. On the other hand, high values indicate a slightly differentiated employment structure.

For the calculation of the above indicators, data on the number of employees in the main place of work (as of December $31^{\text {st }}$ ), broken down into sections of PKD, were used. These data were purchased from the Information Department of the Polish Central Statistical Office (Główny Urząd Statystyczny - GUS). The period of analysis was limited by the possibility of obtaining comparable data. The time series used for the analysis was a period of relatively dynamic economic growth of the entire Polish economy, as well as of its individual regions. The average annual growth rate of GDP per capita in current prices in Poland in 20082018 (according to the Polish Central Statistical Office) was 5.4\%. Even during the economic slowdown in 2008-2013, it was at a relatively high level of $4.9 \%$. Thus, the Polish economy, one of the few in the European Union, did not record a negative dynamics of economic growth during the global economic crisis initiated by the breakdown of the US real estate market (Mihaela et al., 2017, MuchaLeszko, 2020).

However, it should also be emphasized that the processes of economic growth were noticeably differentiated regionally. The voivodships located in central and western Poland - Mazowieckie, Wielkopolskie, Dolnośląskie and Pomorskie - were the fastest growing areas. These were regions with a relatively modern production structure, a well-developed network of cities, and at least one large city described as a metropolis or a potential metropolis (Bogdański, 2018). On the other hand, the four voivodships included in the study belonged to the slowest developing regions in Poland. The average annual growth rate of GDP per capita in 20082018 ranged from $4.7 \%$ in the Warmińsko-Mazurskie Voivodeship to $5.4 \%$ in the Podkarpackie Voivodeship.

As a result, the average value of GDP per capita of the surveyed voivodeships in relation to the national average decreased from $72.3 \%$ in 2008 to $69.8 \%$ in 2018 (the most significant decrease was recorded in Warmińsko-Mazurskie - by $4.7 \%$, and the smallest in Podkarpackie where it was at the level of 1 percentage point). However, it is worth emphasising that while the processes of regional economic divergence could be observed at the national level in the analysed period, the development disparities decreased compared to the EU average. Thus, in 20082018, the four analysed voivodeships reduced the difference in the level of economic growth, measured with GDP per capita, by an average of $2.5 \%$. This distance decreased the most in the Podkarpackie Voivodeship (by 3.2\%) and the least in the Warmińsko-Mazurskie Voivodeship (by 1.4\%).

The surveyed group consisted of all small towns in four voivodships forming the so-called eastern wall of Poland, a part of the country which borders exsocialist countries like Russia, Lithuania, Belarus and Ukraine. 


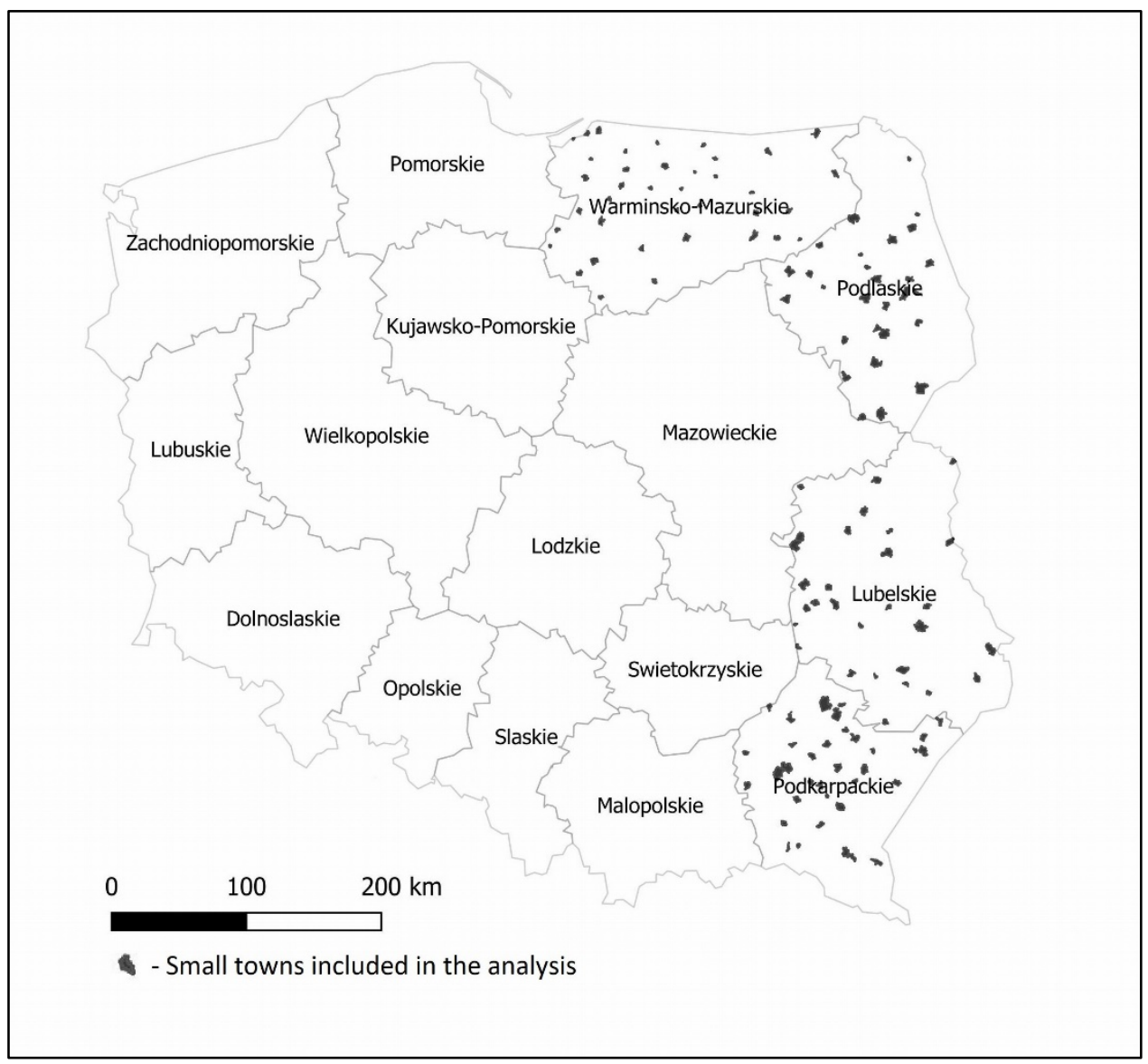

Figure 1. Small towns in eastern Polish voivodeships.

This consist of a total of 131 towns (as of December $31^{\text {st }}, 2008$ ), including 38 towns from Warmińsko-Mazurskie, 28 from Podlaskie, 29 from Lubelskie and 36 from Podkarpackie. The basic criterion used to determine the size of the city was the number of its inhabitants. According to the criteria used by the Polish Central Statistical Office, small towns include those with less than 20,000 inhabitants. The location of the studied towns is presented in Figure 1.

In 2008, the studied towns constituted $77 \%$ of all cities in the analysed voivodships. At the same time, they were inhabited by $27.7 \%$ of the total urban population. Similar values for the whole country amounted to $76.2 \%$ and $21.6 \%$. It indicates the relatively greater importance of small towns in the eastern voivodships than in the rest of the country. It is also due to the specific structure of the settlement network in the aforementioned voivodships where large cities, with over 100,000 residents, play a minor role. With the exception of WarmińskoMazurskie, where there are two large cities, in each of the remaining voivodeships, there is only one city with a population exceeding 100,000. It means that a relatively large part of eastern Poland is outside the catchment area of large cities. In such regions, higher-order functions (like education, healthcare, culture) have to be supplied by small and medium-sized towns. 


\section{Results}

Figure 2 presents data on the functional structure of small towns in the Warmińsko-Mazurskie voivodship in 2008 and 2018. A synthetic summary of the results for this voivodship also can be found in Table 1. From their analysis, one can observe that industrial production played the most prominent role among the functions performed by small municipalities in this region. In 2008 in 20 towns $(52.6 \%$ of all cities in the region), industrial activities dominated the economic base structure (exogenous sector). Until 2018 the number of towns where most workers in the exogenous sector were employed in industrial activities increased to $21(55.3 \%)$. Additionally, in four of them, industry was responsible for $100 \%$ of exogenous employment.

The dominance of industry in the structure of functions performed by the studied towns is also emphasized by the fact that among the total number of people employed in exogenous activities in 2018, the most significant part $(66.9 \%$, compared to $33.6 \%$ in 2008) was employed in section C (industrial processing) of the PKD.

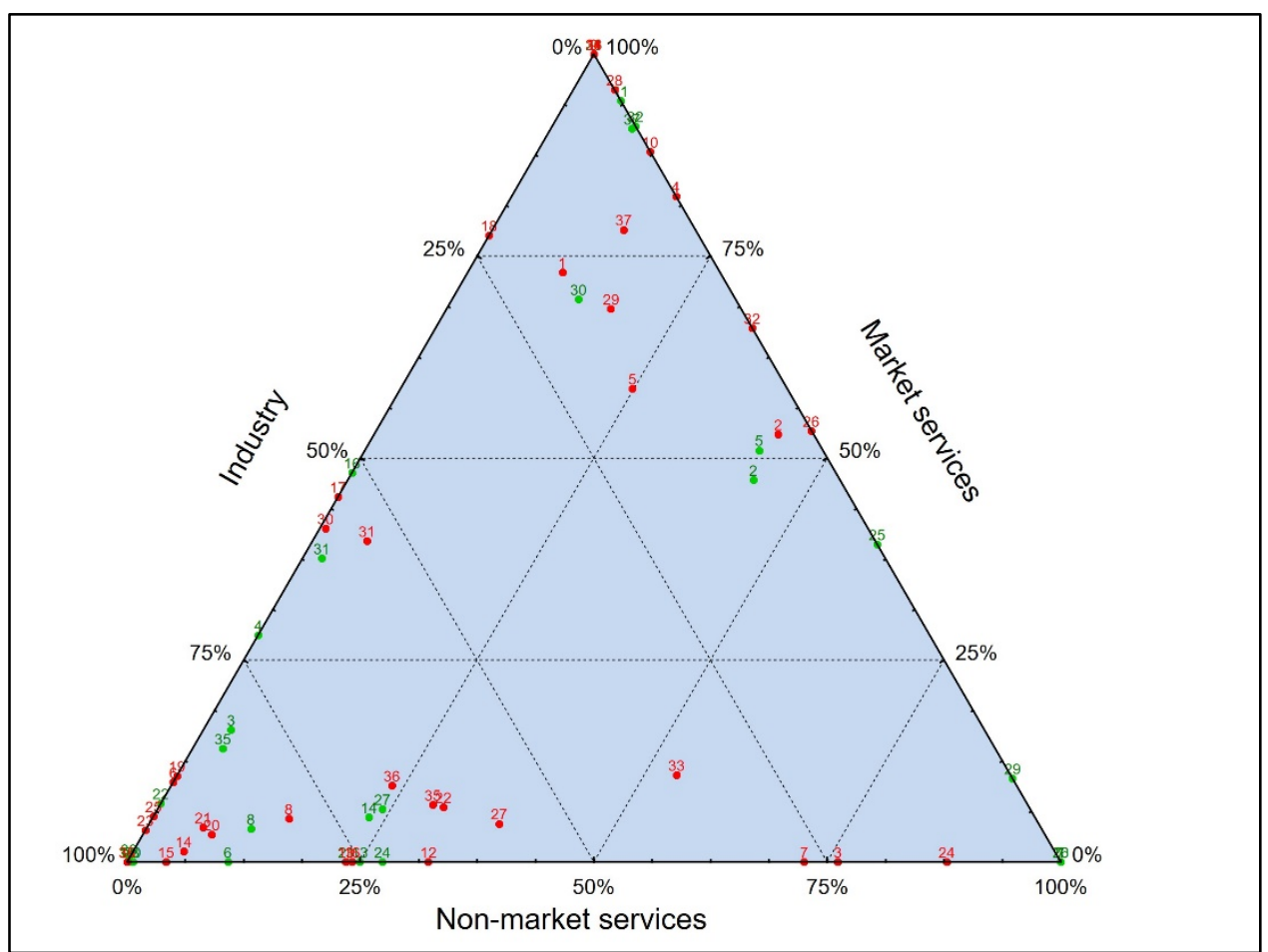

Figure 2. Functional structure of small towns in the Warmińsko-Mazurskie voivodship in 2008 (in red) and 2018 (in green)

Note: 1. Barczewo, 2. Biała Piska, 3. Biskupiec, 4. Bisztynek, 5. Braniewo, 6. Dobre Miasto, 7. Frombork, 8. Gołdap, 9. Górowo Iławeckie, 10. Jeziorany, 11. Kisielice, 12. Korsze, 13. Lidzbark, 14. Lidzbark Warmiński, 15. Lubawa, 16. Mikołajki, 17. Miłakowo, 18. Miłomłyn, 19. Młynary, 20. Morąg, 21. Nidzica, 22. Nowe Miasto Lubawskie, 23. Olecko, 24. Olsztynek, 25. Orneta, 26. Orzysz, 27. Pasłęk, 28. Pasym, 29. Pieniężno, 30. Pisz, 31. Reszel, 32. Ruciane-Nida, 33. Ryn, 34. Sępopol, 35. Susz, 36. Tolkmicko, 37. Węgorzewo, 38. Zalewo

Source: author's calculations. 
Table 1. Structure of the towns in Warmińsko-Mazurskie voivodship by their dominant function in 2008 and 2018

\begin{tabular}{ccccc}
\hline Year & & \multicolumn{3}{c}{ Number of towns } \\
& $\begin{array}{c}\text { I - industrial } \\
\text { (in \%) }\end{array}$ & $\begin{array}{c}\mathrm{M} \text { - market services } \\
\text { (in \%) }\end{array}$ & $\begin{array}{c}\text { N - non-market } \\
\text { services (in \%) }\end{array}$ & Mixed - MN (in \%) \\
\hline 2008 & $20(52.6 \%)$ & $4(10.6 \%)$ & $14(36.8 \%)$ & 0 \\
$2018 *$ & $21(55.3 \%)$ & $6(15.8 \%)$ & $8(21.1 \%)$ & $2(5.3 \%)$ \\
\hline
\end{tabular}

Source: author's calculations.

*In 2018 , one town had no surplus employment, so the results do not sum up to $100 \%$.

It was followed by section $Q$ (health care and social assistance) with a share of $6.4 \%$ and section $\mathrm{P}$ (education) with a share of nearly $5 \%$. The importance of industry in the economies of small towns in Warmińsko-Mazurskie is also illustrated by the fact that the average amount of surplus employment in I-type towns in 2018 was 452 workers. In N-type towns, it was 173 workers and 139 workers in towns with the dominance of market services. The second most important production sector in the functional structure of small towns in Warmińsko-Mazurskie voivodship was non-market services. In 2018 in 8 (21. 1\%) of the studied towns (compared to 14 [36.8\%] in 2008), the functional structure was dominated by non-market services.

This group primarily consisted of the smallest towns, which were additionally characterized by a peripheral location in relation to the capital of the voivodeship - the largest and most developed city in the region - Olsztyn. The location away from big cities meant that some of the public services (education, health care or social welfare) that are usually offered in larger units have to be provided by local authorities. This partially explains the relatively higher share of non-market services in the functional structure of the above towns. At the same time, it also indirectly points to a relatively low economic potential of the discussed centres. Local demand for goods and services is at a low level due to low population numbers and a low level of economic growth, so the private enterprises do not have the capacity to increase production and employment. As a result, the public sector dominates in the economic activities carried out in those towns.

Market services were relatively the least important sector in the functional structure of small towns in Warmińsko-Mazurskie. In 2008, only in 4 towns $(10.6 \%)$ and in 2018 , only in 6 of them (15.8\%) employment in the market services sector accounted for at least $75 \%$ of excess employment. It should be noted that, as in the case of the previous group, these were usually very small towns with modest exogenous employment.

The functional structure of small towns in Warmińsko-Mazurskie was also relatively stable. During the analysed period in $23(60.5 \%)$ towns the dominant type of production did not change. In $6(15.7 \%)$ municipalities a change from type $\mathrm{N}$ or I to type $\mathrm{M}$ was observed which should be assessed positively in view of presented analysis. On the other hand, in 5 centres there was a change in the dominant function from I or M to $\mathrm{N}$. 


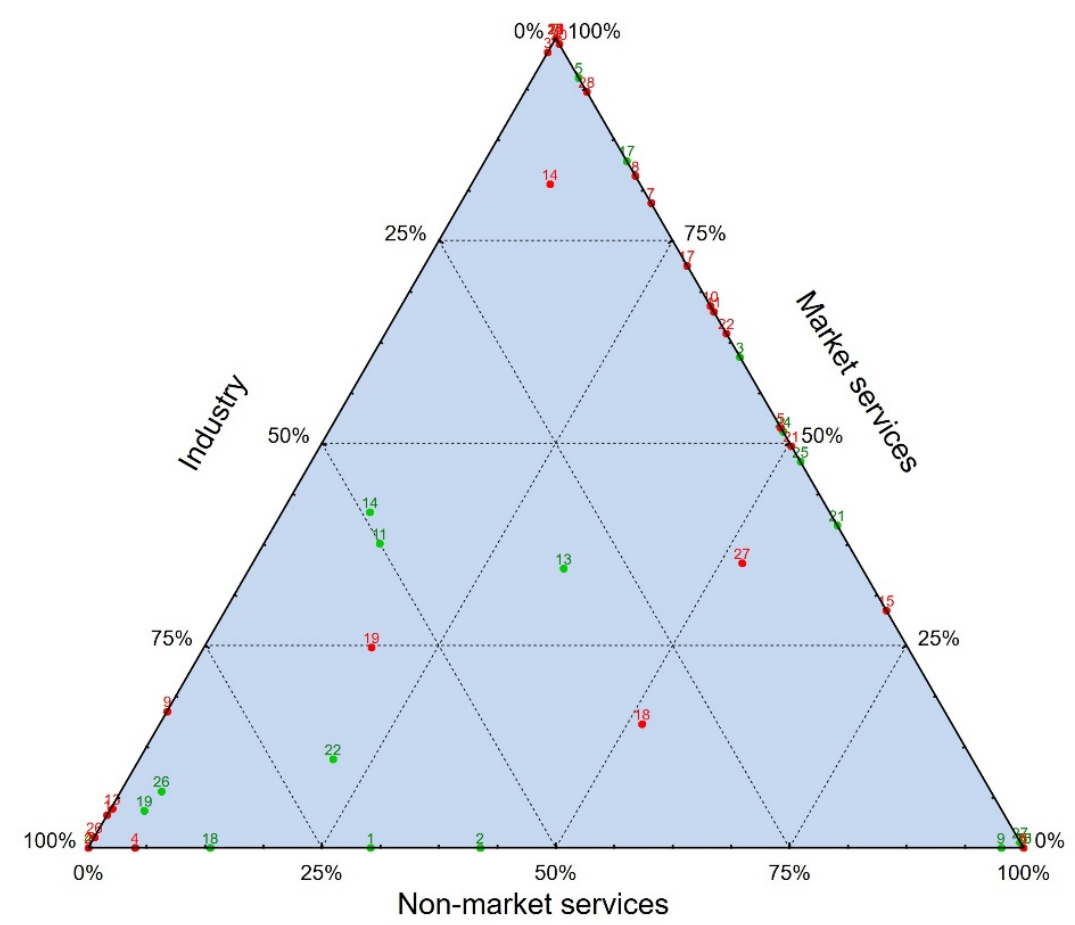

Figure 3. Functional structure of small towns in the Podlaskie voivodship in 2008 (in red) and 2018 (in green)

Note: 1. Brańsk, 2. Choroszcz, 3. Ciechanowiec, 4. Czarna Białostocka, 5. Dąbrowa Białostocka , 6. Drohiczyn, 7. Goniądz, 8. Jedwabne, 9. Kleszczele, 10. Knyszyn, 11. Kolno, 12. Lipsk, 13. Łapy, 14. Mońki, 15. Nowogród, 16. Rajgród, 17. Sejny, 18. Siemiatycze, 19. Sokółka, 20. Stawiski, 21. Suchowola, 22. Supraśl, 23. Suraż, 24. Szczuczyn, 25. Tykocin, 26. Wasilków, 27. Wysokie Mazowieckie, 28. Zabłudów Source: author's calculations.

As far as the diversification of functions performed by small towns in the region is concerned, it was low. IED values in 2008 and 2018 amounted to 546 and 659 units, respectively, which proves a homogeneous functional structure.

In Podlaskie Voivodship (Figure 3, Table 2), one can speak of a distinctly different characteristic of the functional structure of small towns. In 2008 half (14) of the small towns in the region were characterized by absolute dominance of nonmarket services in their economic base structure. Moreover, in 8 of such towns $(28.6 \%)$, the total surplus employment was concentrated in this sector. This situation was typical for the smallest units which were located at a relatively significant distance from large and medium-sized cities. However, in 2018 the number of small towns with a dominant function related to non-market services decreased to 6 (21.4\%). Moreover, only in 3 of them, $100 \%$ of the economic base sector employees, were involved in non-market services. The functions related to industry and market services were of similar importance. When it comes to industrial activity, both in 2008 and 2018, it dominated the economic base structure of $8(28.6 \%)$ small towns. Usually, these were the largest towns included in the study; therefore, this sector had a relatively significant impact on the situation of the local economy. 
Table 2. Structure of the towns in Podlaskie voivodship by their dominant function in 2008 and 2018

\begin{tabular}{ccccccc}
\hline Year & \multicolumn{5}{c}{ Number of towns } \\
& $\begin{array}{c}\text { I - industrial } \\
\text { (in \%) }\end{array}$ & $\begin{array}{c}\text { M - market } \\
\text { services (in \%) }\end{array}$ & $\begin{array}{c}\text { N - non-market } \\
\text { services (in \%) }\end{array}$ & $\begin{array}{c}\text { Mixed - IN } \\
\text { (in \%) }\end{array}$ & $\begin{array}{c}\text { Mixed - } \\
\text { NM (in \%) }\end{array}$ & Balanced \\
\hline $2008^{*}$ & $8(28.6 \%)$ & $5(17.9 \%)$ & $14(50.0 \%)$ & 0 & 0 & 0 \\
$2018 * *$ & $8(28.6 \%)$ & $7(25.0 \%)$ & $6(21.4 \%)$ & $1(3.6 \%)$ & $1(3.6 \%)$ & $1(3.6 \%)$ \\
\hline
\end{tabular}

Source: author's calculations.

*In 2008 , one town had no surplus employment, so the results do not sum up to $100 \%$.

**In 2018 , four towns had no surplus employment, so the results do not sum up to $100 \%$.

In 2018 in small towns of I-type in Podlaskie, an average of 373 workers were employed in the exogenous sector, while in towns of type $\mathrm{M}$ and $\mathrm{N}$, the average surplus of employees was 61 and 114 workers, respectively.

In 2008 the market services sector dominated the employment structure in 5 small towns (17.9\%) in Podlaskie. These were mainly small municipalities, even compared to the studied group. Their relatively peripheral location probably determined their functional structure in relation to large cities with the simultaneous potential for tourism development. In 2018 the number of towns where market services dominated the structure of surplus employment increased to $7(25 \%)$. This may indicate a positive tendency in the evolution of the functional structure of small towns in Podlaskie. However, the relatively small sizes of the economic base of these towns suggest that the service sector generates relatively weak growth impulses for the towns themselves and the surrounding areas. Considering the structure of surplus employment in all of the small towns in Podlaskie broken down into PKD sections, the largest part of the employed fell into sections: $\mathrm{C}$ - industrial processing $(52.5 \%)$, P - education (11.0\%) and $\mathrm{Q}$ health care and social assistance $(6.3 \%), \mathrm{O}$ - public administration and national defence $(6.1 \%)$. As in the case of Warmińsko-Mazurskie the level of diversification of the economic base of small towns in Podlaskie was low; the average IED value in 2008 was 658 units and 697 units in 2018. Again, it indicates a homogeneous economic base structure. Finally, it should be emphasized that in the case of 14 towns $(50 \%)$, no changes in the dominant function were observed during the analysed period (mainly it was I-type and N-type towns). In one municipality, one could talk about a negative trend in the evolution of the functional structure evolution from $\mathrm{M}$ to I-type. On the other hand, in the case of 7 centres (25\%), there was a positive trend observed - that is about the evolution from type $\mathrm{N}$ or I towards a more significant share of market services.

In some respects, the small towns of Lubelskie Voivodship (Figure 4, Table 3) were characterized by a similar functional structure as small municipalities in Podlaskie. Out of 29 towns, both in 2008 and 2018, 12 (41.3\%) could be described as N-type towns. However, it should be emphasized that in the case of this voivodeship, N-type towns had a relatively more significant excess employment. The average size of the economic base in this group reached 398 workers. 
Table 3. Structure of the towns in Lubelskie voivodship by their dominant function in 2008 and 2018

\begin{tabular}{|c|c|c|c|c|c|}
\hline \multirow[t]{2}{*}{ Year } & \multicolumn{5}{|c|}{ Number of towns } \\
\hline & $\begin{array}{c}\text { I - industrial } \\
\text { (in \%) }\end{array}$ & $\begin{array}{c}\mathrm{M}-\text { market } \\
\text { services (in \%) }\end{array}$ & $\begin{array}{l}\mathrm{N} \text { - non-market } \\
\text { services (in \%) }\end{array}$ & $\begin{array}{l}\text { Mixed - IM } \\
\quad \text { (in \%) }\end{array}$ & $\begin{array}{l}\text { Mixed - NI } \\
\text { (in \%) }\end{array}$ \\
\hline 2008 & $9(31 \%)$ & $7(24.1 \%)$ & $12(41.3 \%)$ & $1(2.7 \%)$ & $0(0 \%)$ \\
\hline $2018^{*}$ & $10(34.5 \%)$ & $4(13.8 \%)$ & $12(41.3 \%)$ & $0(0 \%)$ & $1(2.7 \%)$ \\
\hline
\end{tabular}

Source: author's calculations.

*In 2018, two towns had no surplus employment, so the results do not sum up to $100 \%$.

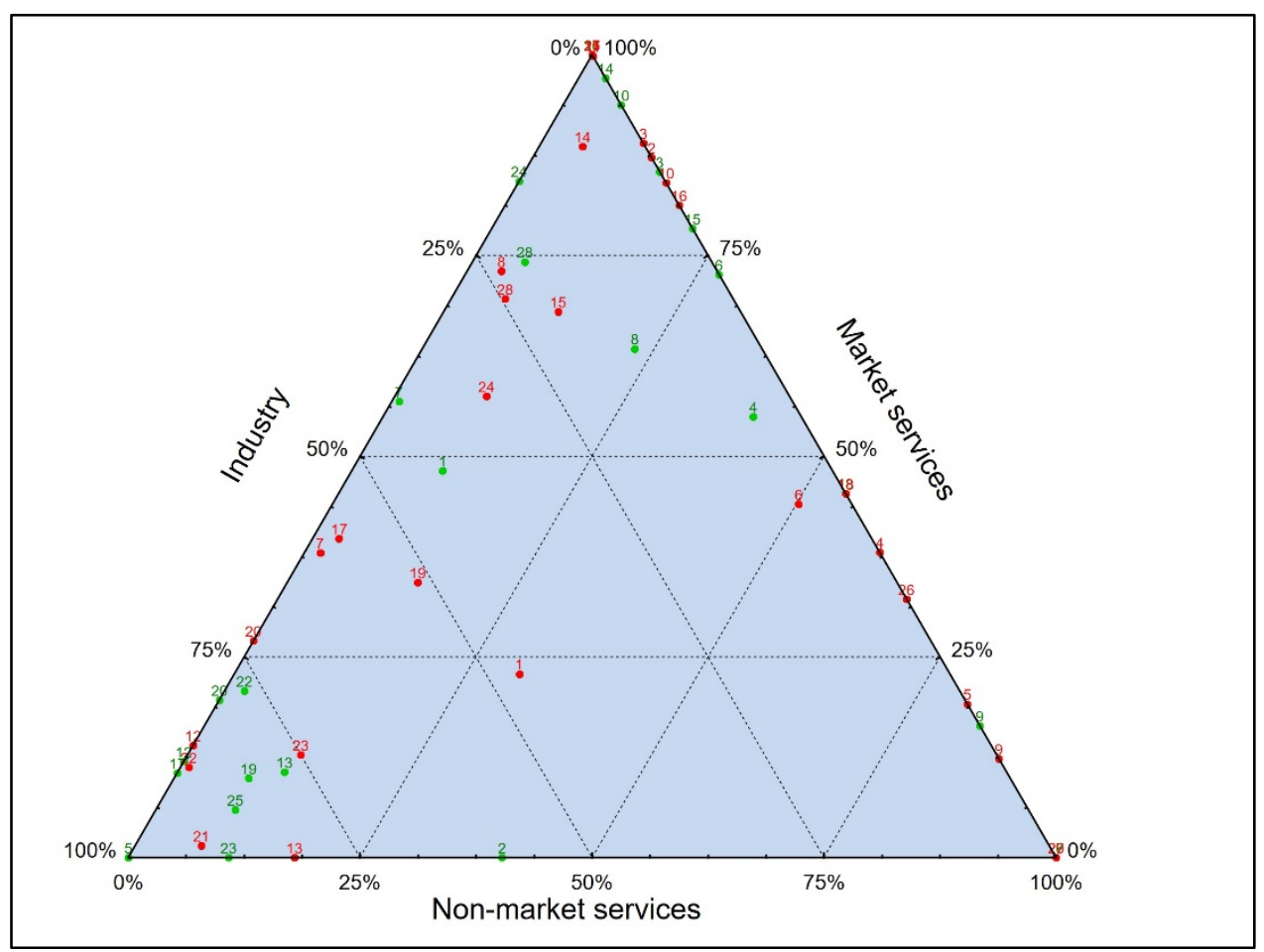

Figure 4. Functional structure of small towns in the Lubelskie voivodship in 2008 (in red) and 2018 (in green)

Note: 1. Annopol, 2. Betżyce, 3. Bychawa, 4. Dęblin, 5. Frampol , 6. Hrubieszów, 7. Janów Lubelski, 8. Józefów, 9. Kazimierz Dolny, 10. Kock, 11. Krasnobród, 12. Krasnystaw, 13. Międzyrzec Podlaski, 14. Nałęczów, 15. Opole Lubelskie, 16. Ostrów Lubelski, 17. Parczew, 18. Piaski, 19. Poniatowa, 20. Radzyń Podlaski, 21. Rejowiec Fabryczny, 22. Ryki, 23. Stoczek Łukowski, 24. Szczebrzeszyn, 25. Tarnogród, 26. Terespol, 27. Tyszowce, 28. Włodawa, 29. Zwierzyniec

Source: author's calculations.

However, among them were towns in which surplus employment was as high as 649 (Włodawa) or 822 (Janów Lubelski), while in some other N-type towns, it was much less. The industry was an important sector within the functions performed by small towns in this region. In 2008 there were $9(31 \%)$ and a decade later 10 towns $(34.5 \%)$ where more than $3 / 4$ of the surplus employment fell in this sector. Furthermore, as in the case of the previous voivodships, the I-type towns were dominated by the largest towns included in the study, where the size of surplus employment was also the biggest. 
The market services sector was relatively the least important, both in terms of the number of towns and the number of jobs created. In 2008 this sector dominated the structure of surplus employment in 7 towns (24.1\%). In turn, in 2018, the number of such centres decreased to 4 (13.8\%). It also should be noted that apart from Kazimierz Dolny (a popular Polish tourist attraction) and Terespol (a large border crossing with Belarus), where exogenous employment in 2018 amounted to 240 and 693 workers, respectively in none of such towns did the size of the economic base exceed 100. Therefore, the importance of the market services sector in shaping the economic situation of this type of centre was relatively small. The PKD sections which at the end of the analysed period had the largest share in the total surplus employment of all small towns in Lubelskie Voivodship are sections C - industrial processing (36.8\%), O - public administration and national defence $(12.9 \%)$ and $\mathrm{Q}$ - health care and social assistance (12.5\%). As in the voivodships discussed earlier, the functional structure of small towns in Lubelskie Voivodship was relatively homogeneous (the value of the IED coefficient was 516 units in 2008 and 542 in 2018) and stable. Despite some natural changes in the production structure and the functions performed only in 10 out of 29 small towns, their dominant function experienced change.

Assuming that the large share of services in the structure of production and employment has the biggest, positive effect on the growth of local economies (Christofakis \& Gkouzos 2014), it should be noted that the small towns of Podkarpackie voivodship were characterized by the most advantageous functional structure (Figure 5, Table 4). This region had a relatively large proportion of towns in which at least $75 \%$ of the surplus employment fell in the market services sector. Although in 2008 there were 9 such towns (out of 36 in total) in 2018, their number increased to 12 (33.3\%). Among the surveyed voivodeships, it constituted the most significant percentage of M-type towns. Most of these towns were located in the south of the voivodeship in the Bieszczady Mountains, a popular holiday destination for many Poles. At the same time, it should be mentioned that, as in the case of other voivodships, this sector was characterized by the smallest size in terms of the number of workers. The average surplus employment in 2018 in Mtype towns was 305 workers, while in I-type towns, it was 466 workers, and in Ntype towns, it reached 404 workers. Hence, functions related to market services dominated in the smallest centres with a relatively small size of the economic base.

When analyzing the non-market services sector, the opposite trends could be observed. At the beginning of the analysed period, the number of towns where this function was dominant reached 14 (38.8\%). In 2018 this number decreased to $12(33.3 \%)$. Also, the size of the exogenous employment in most of the N-type towns decreased. Industrial functions were dominant in 11 urban centres (30.6\%), both in 2008 and 2018. The dominance of industry-related functions was typical for the largest of the analysed towns, usually located relatively close to Rzeszów (regions capital) or Sanok and Tarnów - other industrial centres significant for Podkarpackie and neighbouring Małopolskie voivodeship. Importantly, in the case of Podkarpackie, modern production branches related to the aviation industry constitute an essential part of industrial production. 
Table 4. Structure of the towns in Podkarpackie voivodship by their dominant function in 2008 and 2018

\begin{tabular}{ccccc}
\hline Year & & \multicolumn{3}{c}{ Number of towns } \\
& $\mathrm{I}$ - industrial & $\mathrm{M}$ - market services & $\mathrm{N}$ - non-market services & Mixed - IN \\
\hline 2008 & $11(30.6 \%)$ & $9(25 \%)$ & $14(38.8 \%)$ & $2(5.6 \%)$ \\
2018 & $11(30.6 \%)$ & $12(33.3 \%)$ & $12(33.3 \%)$ & $1(2.8 \%)$ \\
\hline
\end{tabular}

Source: author's calculations.

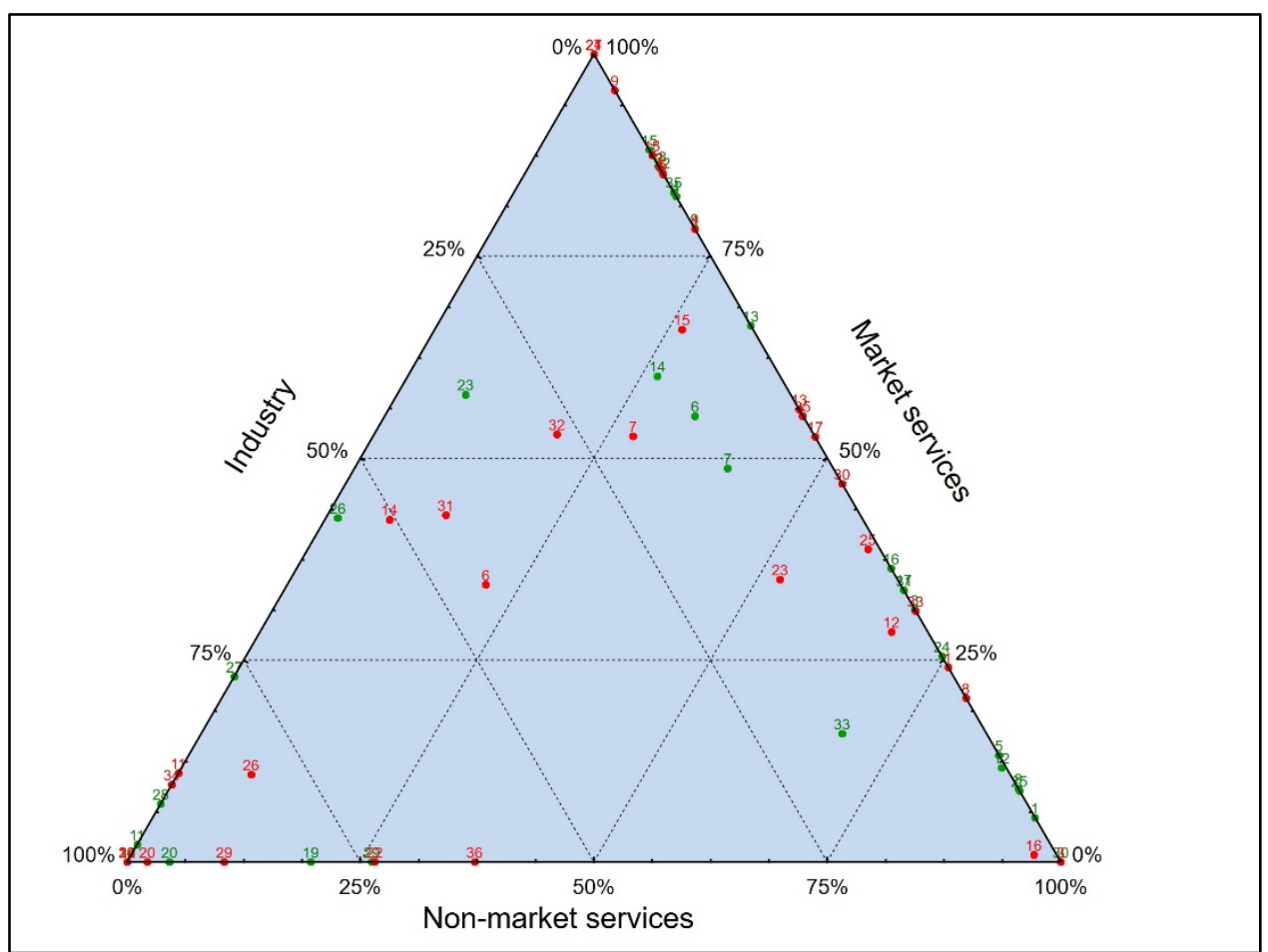

Figure 5. Functional structure of small towns in the Podkarpackie voivodship in 2008 (in red) and 2018 (in green)

Note: 1. Baranów Sandomierski, 2. Błażowa, 3. Boguchwała, 4. Brzozów, 5. Cieszanów, 6. Dukla, 7. Dynów, 8. Głogów Małopolski, 9. Iwonicz-Zdrój, 10. Jedlicze, 11. Kańczuga, 12. Kolbuszowa, 13. Lesko, 14. Leżajsk, 15. Lubaczów, 16. Łańcut, 17. Narol, 18. Nisko, 19. Nowa Dęba, 20. Nowa Sarzyna, 21. Oleszyce, 22. Pilzno, 23. Przeworsk, 24. Radomyśl Wielki, 25. Radymno, 26. Ropczyce, 27. Rudnik nad Sanem, 28. Rymanów, 29. Sędziszów Małopolski, 30. Sieniawa, 31. Sokołów Małopolski, 32. Strzyżów, 33. Tyczyn, 34. Ulanów, 35. Ustrzyki Dolne, 36. Zagórz

Source: author's calculations.

Thanks to the long-lasting production traditions, scientific and infrastructural facilities and relatively good transport accessibility, 90\% of Polish aviation industry production is made in Podkarpackie. The aviation industry, due to its specificity, can be a significant source of economic growth for local, regional and national economies. It generates relatively high added value to the economy and creates relatively well paid stable employment. Hence, it can be assumed that in the case of this voivodeship, a large share of industry in the functional structure of small towns may be a significant growth stimulus. 
Small towns in Podkarpackie had in 2018 the largest share in the total surplus employment in the following PKD sections: C - industrial processing (30.4\%), G - wholesale and retail trade, repair of motor vehicles - with a share of $12.8 \%$ and section $\mathrm{O}$ - public administration and national defence - with a $12.5 \%$ share. IED values were 555 units in 2008 and 533 units in 2018, which indicates a homogeneous, relatively low diversified economic base. It was also relatively stable - in the analysed period, only in $9(25 \%)$ towns, the dominant function has changed.

\section{Discussions}

In many aspects, the analysed voivodeships constitute a relatively homogeneous group. Their common features are, among others, peripheral location at the eastern border of Poland and the European Union, a relatively small population and low population density (compared to other regions in Poland), poorly developed technical and social infrastructure, uncompetitive production structure (Bogdański, 2017b; Piszcz \& Klonowska-Matynia, 2018). The socioeconomic potential of the surveyed voivodships is also limited by a poorly developed settlement network.

Within this macroregion, one can also observe continuing concentration of the human, social and economic potential in the biggest cities. It leads to the marginalization of small and medium-sized towns and surrounding areas and growing disproportions in the level of economic growth (Bogdański, 2017a; Olejniczak-Korcelli, 2020). Many small and medium-sized towns in the analysed regions are affected by the problems of depopulation, a relative decline in the quality of life, a deterioration in the scale and scope of public services provided. Notably, the above problems are typical for many small and medium-sized towns located in different countries of Central and Eastern Europe, which after 1989, underwent the process of economic transformation from socialism towards a freemarket economy (Hlvacek et al., 2020; Hasse et al., 2017; Wolf \& Wiechmann, 2018). Nevertheless, despite a continued decline in their socio-economic potential, small towns in such regions are still significant in stimulating economic growth and an improvement in the quality of life (Vaishar et al., 2016; Servillo \& Russo, 2017; Stoica et al., 2020). Moreover, as experiences of other developed economies in Europe show, improvement in these areas requires small towns to develop diversified, modern and competitive production structures with a relatively low share of industry and public sector (Hamdouch et al., 2017).

The analyses presented in the paper allow concluding that the changes taking place in the functional structure of small towns in four voivodeships of eastern Poland will result in a further increase of the already existing disproportions of the economic growth level. There are several reasons for this.

Firstly, the overall production structure of the studied towns is dominated by industrial processing with a low level of technological advancement and high price sensibility (with the exception of the aviation industry in Podkarpackie). In the 
case of this type of activity the producers' competitive advantage depends on low production costs, especially on low labour costs. Therefore, the employers generate demand mainly for unskilled labour, offering relatively low wages (Merlo et al., 2015; Wesołowska, 2018). It means that the income obtained in the analysed regions is not a significant factor that could stimulate the growth of demand, production and employment. This thesis is also supported by Servillo (2014), who shows that small and medium-sized towns which initially were more dependent on industry performed less well than towns with a higher share of services in their functional structure.

Secondly, the analysis carried out in the paper allows us to state that the small towns of eastern Poland had a relatively homogenous production structure. IED values for all of the voivodships were relatively high in 2008, and they did not change significantly during the next ten years. This had and probably will have a negative impact on the level of economic resilience of towns, increasing the risk of large, unfavourable fluctuations in production and employment in the face of a collapse in external demand (Drobniak, 2014; Tóth, 2015).

In the case of N-type towns, one can also speak of significant barriers to future economic growth. Towns of this type usually belonged to the smallest of the analysed centres. The domination of the non-market services resulted not from a high level of development of this sector but the weakness of other economic functions. In other words, there is no or minimal potential for creating jobs outside the public sector (Himstedt, 2017). Additionally, considering the scale of underinvestment of the public sector (both local and governmental) in Poland, the country's growing budget debt, unfavourable demographic trends which will result in further limitations in the scale of non-market services provided (closing of schools, health centres), one can expect that the potential for economic growth of such towns will continue to decline (Bogdański, 2017a).

At the same time, it is difficult to expect that the conditions for regional convergence will develop soon. This is because the settlement network's structure, form, and functions are such permanent elements of regional socio-economic systems that any correction in the short and medium term is extremely difficult and requires selecting adequate and effective economic policy tools.

Comparing the obtained results with other studies on the socio-economic performance of small towns in other Eastern and Central European countries, one can observe some similarities. First of all, it seems that the growth potential of small towns strongly depends on their size and the distance to big cities. Furthermore, among the studied units, the worst state of the functional structure, size of the urban economic base, and product diversification were typical for the smallest towns located away from big cities.

The same patterns were observed in Slovakia (Novotny et al., 2016), the Czech Republic (Vaishar et al., 2016), Moldova (Lupascu, 2020) and Romania (Stoica et al., 2020). Even though the authors of these studies assess the socio-economic situation in various ways - from calculating the Index of Urban Strength (ISU) (Stoica et al., 2020), through analysing different levels of sustainability (Vaishar et al., 2016), up to defining multi-criteria development trajectories of small towns 
(Novotny et al., 2016), the overall conclusions are similar. What is worrying is the fact that such a combination of the above features in German and Japanese small towns, along with depopulation and ageing structure of inhabitants, created a downward spiral which led to the further peripheralization and economic decline of such cities (Wirth et al., 2016).

\section{Conclusions}

The analysis carried out showed that small towns located in the eastern Polish voivodships, just like small towns in Slovakia and Romania (Novotny et al., 2016, Stoica et al., 2020), need a relatively long term to change their production structure into a more modern and competitive one, especially when they are old, industrial centres developed during socialist regime. Only the towns that had some tourist or recreation potential or were located in the proximity of big cities and thus were able to take advantage of their proximity and create some economic potential towards future economic development. This explains why in postcommunist economies, unlike in the western European countries, many small towns, especially those located outside of highly urbanised regions, tend to have relatively low growth dynamics (Pirisi et al., 2015).

To conclude, the presented analysis puts some new perspective on the knowledge about the functional structure of small towns located in the least developed regions in Poland. It shows the evolution of this structure between 2008 and 2018. Considering the similarities with other ex-socialist countries, it also might be useful to explain their growth dynamics and spatial diversification of this process. The study also proves that the theory of urban economic base gives some foundations for a better understanding of the economies of small towns. Finally, the study provides arguments to state that one of the reasons for a lower level of economic development of Eastern Poland is connected with the overall socio-economic situation of small towns which dominate the urban network in this macroregion. However, the link between the two latter categories is not clear and needs further analysis, which will determine the direction of the author's future research.

\section{References}

Bell, D. and Jayne, M. (2009), Cities in Contemporary Europe, Cambridge University Press, Cambridge.

Black, D. and Henderson, J.V. (2003), "Urban evolution in the US", Journal of Economic Geography, vol. 3 no. 4, p. 343-375.

Bogdański, M. (2017a), "Wybrane zagrożenia dla rozwoju małych i średnich miast w Polsce", Samorzad Terytorialny, vol. 3, p. 5-17. 
Bogdański, M. (2017b), "Regional development in Poland" in E.M.P Silva and L.S. Clarisse Pais (eds), Teaching Crossroads: 12th IPB Erasmus Week, Instituto Politécnico de Bragança, Bragança, Portugal, p. 13-30.

Bogdański, M. (2018), "Ewolucja bazy ekonomicznej a wzrost gospodarczy miast wojewódzkich", Prace Naukowe Uniwersytetu Ekonomicznego we Wrocławiu, vol. 536, p. 21-38.

Brenner, N. and Schmid, C. (2014), "The "Urban Age" in Question", International Journal of Urban and Regional Research, vol. 38, no. 3, p. 731-755.

Brunelle, C. (2013), "The Growing Specialization of Cities: Disentangling Industrial and Functional Dimensions in the Canadian Urban System, 19712006", Growth and Change, vol. 44, no. 3, p. 443-473.

Christofakis, M. and Gkouzos, A. (2014), "Exploration of Localness in the Context of Economic Base: Accessing Evidence from Greek Prefectures", Urban $\mathcal{\sigma}^{\circ}$ Regional Development Studies, vol. 26, p. 189-202.

Cienkosz, E. (2020), "Demograficzny aspekt kurczenia się polskich miast", Urban Development Issues, vol. 67, p. 45-56.

Czapiewski, K., Bański, J. and Górczyńska, M. (2016), "The impact of location on the role of small towns in regional development: Mazovia, Poland", European Countryside, vol. 8, no. 4, p. 413-426.

Czornik, M. (2004), Miasto. Ekonomiczne aspekty funkcjonowania, Wydawnictwo Akademii Ekonomicznej im. K. Adamieckiego w Katowicach, Katowice, Poland.

David, Q., Peeters, D., Van Hamme, G. and Vandermotten, C. (2013), "Is bigger better? Economic Performance of European Cities, 1960-2009", Cities, vol. 35, p. 237-254.

Davidson, M. and Iveson, K. (2015), "Beyond City Limits: A Conceptual and Political Defense of "the City" as an Anchoring Concept for Critical Urban Theory", City, vol. 19, no. 5, p. 646-664.

Dijkstra, L., Garcilazo, E. and McCann, P. (2013), "The Economic Performance of European Cities and City Regions: Myths and Realities", European Planning Studies, vol. 21, no. 3, p. 334-354.

Drobniak, A. (2014), "Urban resilience and post-industrial city" in A. Drobniak (ed), Urban Resilience Concept and Post-Industrial Cites in Europe, Uniwersytet Ekonomiczny w Katowicach, Katowice, Poland, p. 15-28.

Duranton, G. and Puga, D. (2000), "Diversity and Specialisation in Cities: Why, Where and When Does it Matter?", Urban Studies, vol. 37, p. 533-555.

Erickcek, G.A. and McKinney, H. (2006), "Small Cities Blues: Looking for growth factors in small and medium-sized cities", Economic Development Quarterly, vol. 20, no. 3, p. 232-258.

European Union (2011), Cities of Tomorrow. Challenges, Visions, Ways Forward, European Commission, Brussles.

Górak, K. and Krysiński, D. (2017), "Odwracalny regres? Małe i średnie miasta w świetle wyzwań społeczno-ekonomicznych oraz koncepcji zaradczych - przykład Dolnego Śląska", Miasto. Pamięć i przyszłość, vol. 2, p. 121-136.

Guan, H., Liu, W., Zhang, P., Lo, K., Li, J. and Li, L. (2018), "Analyzing Industrial Structure Evolution of Old Industrial Cities Using Evolutionary Resilience 
Theory: A Case Study in Shenyang of China", Chinese Geographical Science, vol. 28, no. 3, p. 516-528.

Hamdouch, A., Demaziere, C. and Banovic, K. (2017), "The Socio-Economic Profiles of Small and Medium-Sized Towns: Insights from European Case Studies", Tijdschrift voor economische en sociale geografie, vol. 108, no. 4, p. 456-471.

Hasse, A., Rink, D. and Grossmann, K. (2017), "Shrinking cities in post-socialist Europe: what can we learn from their analysis for theory building today?", Geografiska Annaler. Series B. Human Geography, vol. 98. no. 4, p. 305-319.

Heffner, K. and Twardzik, M. (2015), "The impact of shopping centres in rural areas and small towns in the outer metropolitan zone (the example of the Silesian Voivodship)", European Countryside, vol. 7, p. 87-100.

Hlvacek, P., Raska, P. and Balej, M. (2016), "Regeneration projects in Central and Eastern European postcommunist cities: Current trends and community needs", Habitat International, vol. 56, p. 31-41.

Jerczyński, M. (1971), "Metody pośrednie identyfikacji i pomiaru bazy ekonomicznej miast", in Baza ekonomiczna i struktura funkcjonalna miast”, Prace Geograficzne, no. 87, Instytut Geografii Polskiej Akademii Nauk, Warszawa, Poland, p. 111-141.

Kemeny, T. and Storper, M. (2015), "Is Specialization Good for Regional Economic Development?", Regional Studies, vol. 49, no. 6, p. 1003-1018.

Konecka-Szydłowska, B. (2016), "Significance of small towns in the process of urbanisation of the Wielkopolska Region (Poland)", European Countryside, vol. 8, no. 4, p. 444-461.

Krikelas, A.C. (1992), "Why regions grow: A Review of Research On the Economic Base Model", Economic Review, vol. 7, p. 16-29.

Krzysztofik, R. and Szmytke, R. (2018), "Depopulation in Poland in the light of changes in city functions", Przeglad Geograficzny, vol. 90, p. 309-329.

Lazzeroni, M., Bellini, N., Cortesi, G. and Loffredo, A. (2013), "The territorial approach to cultural economy: new opportunities for the development of small towns", European Planning Studies, vol. 21, no. 4, p. 452-472.

Lupascu, M. (2020), "The Role of Small Towns of the Republic of Moldova in the Context of Regional Development", The Journal of Contemporary Economy, vol. 5, no. 1, p. 127-132.

Markusen, A. (2007), "A consumption Base Theory of Development: An Application to the Rural Cultural Economy", Agriculture and Resource Economics Review, vol. 36, p. 9-23.

Masik, G. and Sagan, I. (2016), "Strategie i instrumenty wspierające odporność gospodarczą. Przykład wybranych regionów europejskich", Studia Regionalne $i$ Lokalne, vol. 4, no. 66, p. 5-29.

McFarlane, J., Blackwell, B.D., Mounter, S.W. and Grant, B.J. (2016), "From agriculture to mining: The changing economic base of a rural economy and implications for development", Economic Analysis and Policy, vol. 49, p. 56-65.

Merlo, P., Michalak, J. and Bogdański, M. (2015), "Kapitał ludzki a rynek pracy w województwie warmińsko-mazurskim" in P. Merło and J. Michalak (eds), Efekty inwestowania w kształcenie kadry menadzerskiej dla potrzeb regionalnego rynku pracy, 
Wydział Nauk Ekonomicznych, Uniwersytet Warmińsko-Mazurski w Olsztynie, Olsztyn, Poland, p. 18-32.

Mihaela, S., Lazanyi, K., Sopkova, G., Dobes, K. and Balcerzak, A.P. (2017), "Determinants of Economic Growth in V4 Countries and Romania", Journal of Competitiveness, vol. 9, p. 103-116.

Mucha-Leszko, B. (2020), "Supply- and demand-side sources of economic growth in Poland and the largest EU member states in 2000-2018", Social Inequalities and Economic Growth, vol. 61, p. 7-25.

Novotny, L., Csachova, S., Kulla, M., Nesterova-Dicka and J., Pregi, L. (2016), "Development Trajectories of Small Towns in East Slovakia", European Countryside, vol.8, no. 4, p. 373-394.

Olejniczak-Korcelli, E. (2020), "Functional differentiation of small towns in NorthEastern Poland under a depopulation trend", Przeglad Geograficzny, vol. 92, no. 2, p. 191-212.

Pirisi, G., Trócsányi, A. and Makkai, B. (2015), "Between shrinking and blooming; The crossroad of small towns", Annales Universitatis Paedagogicae Cracoviensis Studia Geographica, vol. 8, p. 12-28.

Piszcz, N. and Klonowska-Matynia, M. (2018), "Uwarunkowania rozwoju społeczno-gospodarczego głównych regionów w Polsce. Wybrane aspekty", Zeszyty Naukowe Wydziału Nauk Ekonomicznych Politechniki Koszalinskiej, vol. 22, p. 259-286.

Porsche, L., Steinführer, A., Beetz, S., Dehne, P., Fina, S., Großmann, K., Leibert, T., Maaß, A., Mayer, H., Milbert, A., Nadler, R. and Sondermann, M. (2019), "Small Town Research in Germany - Status Quo and Recommendations", Position Paper of the ARL 114, Akademie für Raumforschung und Landesplanung, Hanover.

Rutland, T. and O'Hagan S. (2007), "The Growing Localness of the Canadian City, or, On the Continued (Ir)relevance of Economic Base Theory", Local Economy, vol. 2, p. 163-185.

Servillo, L. (2014), "TOWN., Small and Medium Sized Towns in their Functional Territorial Centext", Scientific Report, ESPON, Luxembourg.

Servillo, L., Atkinson, R. and Hamdouch, A. (2017), "Small and Medium-Sized Towns in Europe: Conceptual, Methodological and Policy Issues", Tijdschrift voor economische en sociale geografie, vol. 108, no. 4, p. 456-471.

Servillo, L. and Russo, A.P. (2017), "Spatial Trends of Towns in Europe: The Performance of Regions with Low Degree of Urbanisation", Tijdschrift voor economische en sociale geografie, vol. 108, no. 4, p. 365-379.

Skrzyp, J. (2002), "Polityka rozwoju regionalnego. Wybrane zagadnienia", Publishing House of Akademia Podlaska, Siedlce, Poland.

Smętkowski, M. and Gorzelak, G. (2001), "Nowe relacje między metropolią i regionem w gospodarce informacyjnej", Studia Regionalne i Lokalne, vol. 7, no. 4. Sokołowski, D. (2008), "Baza ekonomiczna większych miast w Polsce w okresie transformacji systemowej", Przeglad Geograficzny, vol. 80, p. 245-266.

Stawasz, D. (2016), Wspótczesne dylematy zarządzania rozwojem miast, Wydawnictwo Uniwersytetu Łódzkiego, Łódź, Poland. 
Steinführer, A. and Grossmann, K. (2021), "Small towns (re)growing old. Hidden dynamics of old age migration in shrinking regions in Germany", Geografiska Annaler: Series B, Human Geography, vol. 103, no. 3.

Stettner, M. (2017), "Zróżnicowanie potencjałów rozwojowych wybranych małych miast w województwie dolnośląskim", Bazekon, vol. 4, p. 56-67.

Stoica, I.V., Tulla, A.F., Zamfir, D. and Petrișor, A.I. (2020), "Exploring the Urban Strength of Small Towns in Romania", Social Indicators Research, vol. 152, p. 843875 .

Suliborski, A. (2010), Funkcjonalizm w polskiej geografii miast, Wydawnictwo Uniwersytetu Łódzkiego, Łódź, Poland.

Świdyński, J. and Świdyńska, N.K. (2018), "Wpływ uwarunkowań geograficznoprzyrodniczych na rozwój małych miast", Space-Society-Economy, vol. 25, p. 75-84.

Thulin, P. (2014), "Local Multiplier and Economic Base Analysis", Working Paper 2014: 29, Swedish Entrepreneurship Forum.

Tóth, B.I. (2015), "Regional economic resilience: Concepts, empirics and a critical review", Miscellanea Geographica, vol. 19.

Vaishar, A., Zapletova, J. and Novakova, E. (2016), "Between urban and rural: sustainability of small towns in the Czech Republic", European Countryside, vol. 8, no. 4 , p. 351-372.

Walkiewicz, D. (2006), Przemiany struktury funkcjonalnej miast wojewódzkich w latach 1975-1995, Wydawnictwo Uniwersytetu Łódzkiego, Łódź, Poland.

Wirth, P., Elis, V., Muller, B. and Yamamoto, K. (2016), "Peripheralisation of small towns in Germany and Japan - Dealing with economic decline and population loss", Journal of Rural Studies, vol. 47, p. 62-75.

Wójcik, M. and Tobiasz-Lis, P. (2016), "Funkcje gospodarcze regionu miejskiego Nowosybirska. Geneza i współczesne trendy rozwojowe", Przeglą Geograficzny, vol. 88, no. 2, p. 183-206.

Wolf, M. and Wiechmann, T. (2018), "Urban growth and decline: Europe's shrinking cities in a comparative perspective 1990-2010", European Urban and Regional Studies, vol. 25, no. 2, p. 122-139.

Wołyniec, Ł. (2019), "Małe miasta pod naporem współczesności. Ujęcie demograficzne" in M. Zemło (ed) Małe miasta: codzienność, Wydawnictwo Uniwersytetu w Białymstoku, Białystok, p. 213-236. 